Meta

Journal des traducteurs

Translators' Journal

\title{
La législation bilingue au Manitoba : le rêve d'une version française faite sur mesure pour son auditoire
}

\section{Guy Jourdain}

Volume 47, numéro 2, juin 2002

Traduction et terminologie juridiques

URI : https://id.erudit.org/iderudit/008013ar

DOI : https://doi.org/10.7202/008013ar

Aller au sommaire du numéro

Éditeur(s)

Les Presses de l'Université de Montréal

ISSN

0026-0452 (imprimé)

1492-1421 (numérique)

Découvrir la revue

Citer cet article

Jourdain, G. (2002). La législation bilingue au Manitoba : le rêve d'une version française faite sur mesure pour son auditoire. Meta, 47(2), 244-264.

https://doi.org/10.7202/008013ar
Résumé de l'article

L'auteur aborde dans un premier temps les faits socio-historiques qui servent de toile de fond, d'une part, à la norme constitutionnelle de bilinguisme législatif au Manitoba et, d'autre part, au besoin d'une réorientation de ses méthodes d'application. Après cette mise en situation, il examine la portée de la norme constitutionnelle en cause et les moyens conventionnels susceptibles d'être employés pour tenter de la mettre en oeuvre. En dernier lieu, il propose un certain nombre de mesures de rattrapage destinées à atténuer les conséquences de 90 ans d'unilinguisme anglais en matière législative et à assurer que, sur le plan de son mode d'expression, la version française de la législation bilingue soit le mieux possible adaptée au public qu'elle vise. À cet effet, il préconise des interventions de trois ordres qui ont respectivement trait à la codification des lois, à la simplification des lois et à la vulgarisation du droit en français. Il conclut en exprimant l'avis que, si une réforme en profondeur n'a pas lieu, l'idéal constitutionnel de bilinguisme législatif pourrait être en péril. 


\section{La législation bilingue au Manitoba: le rêve d'une version française faite sur mesure pour son auditoire}

\section{GUY JOURDAIN}

Palais législatif du Manitoba (Services en langue française), Winnipeg, Canada

(Article préparé pour le compte de la Commission du droit au Canada)

\begin{abstract}
RÉSUMÉ
L'auteur aborde dans un premier temps les faits socio-historiques qui servent de toile de fond, d'une part, à la norme constitutionnelle de bilinguisme législatif au Manitoba et, d'autre part, au besoin d'une réorientation de ses méthodes d'application. Après cette mise en situation, il examine la portée de la norme constitutionnelle en cause et les moyens conventionnels susceptibles d'être employés pour tenter de la mettre en œuvre. En dernier lieu, il propose un certain nombre de mesures de rattrapage destinées à atténuer les conséquences de 90 ans d'unilinguisme anglais en matière législative et à assurer que, sur le plan de son mode d'expression, la version française de la législation bilingue soit le mieux possible adaptée au public qu'elle vise. À cet effet, il préconise des interventions de trois ordres qui ont respectivement trait à la codification des lois, à la simplification des lois et à la vulgarisation du droit en français. II conclut en exprimant l'avis que, si une réforme en profondeur n'a pas lieu, l'idéal constitutionnel de bilinguisme législatif pourrait être en péril.
\end{abstract}

\section{MOTS-CLÉS/KEYWORDS}

législation bilingue, Manitoba, codification de lois, simplification de lois, vulgarisation du droit en français

\section{INTRODUCTION}

L'article 23 de la Loi de 1870 sur le Manitoba ${ }^{1}$ comporte des garanties constitutionnelles en matière de bilinguisme parlementaire, législatif et judiciaire. Dans le Renvoi: Droits linguistiques au Manitoba ${ }^{2}$, la Cour suprême du Canada s'est exprimée comme suit au sujet du but visé par l'article 23: "L'objet de l'article 23 de la Loi de 1870 sur le Manitoba [...] est d'assurer aux francophones et aux anglophones l'accès égal aux corps législatifs, aux lois et aux tribunaux ${ }^{3}$.»

Comme nous le verrons ci-dessous, les garanties en question allaient cependant être abrogées illégalement en 1890 et renaître en 1979 grâce à la

\section{Bilingual Legislation in Manitoba: The Dream of a French Version Tailored to its Audience}

\section{GUY JOURDAIN}

Palais législatif du Manitoba (Services en langue française), Winnipeg, Canada

\begin{abstract}
The author first discusses the social and historical background forming the substance of the constitutional norm of legislative bilingualism in Manitoba, on the one hand, and the need to redirect its application, on the other. He then examines the scope of the constitutional norm in question and the conventional means that may used to implement them. Lastly, he proposes remedial action to counter the effects of 90 years of English legislative unilingualism and ensure that, in its mode of expression, the French version of bilingual legislation is optimally adapted to its target audience. To this end, he proposes three measures, i.e. the codification of laws, the simplification of legislation, and the clarification of the law in French. He concludes by expressing the opinion that, failing in-depth reform, the constitutional ideal of legislative bilingualism may be jeopardized.
\end{abstract}

\section{INTRODUCTION}

Section 23 of the Manitoba Act, $1870^{1}$ includes constitutional guarantees in matters of parliamentary, legislative, and judicial bilingualism. In Reference Re Manitoba Language Rights, ${ }^{2}$ the Supreme Court of Canada, in discussing the purpose of section 23, stated that " $[\mathrm{t}]$ he purpose of . . . section 23 of the Manitoba Act, 1870 . . was to ensure equal access to the legislatures, the laws and the courts for francophones and anglophones alike."

As we shall see below, the guarantees in question were illegally abrogated in 1890 but revived in 1979 as a result of the celebrated Forest case. ${ }^{4}$ Thus, for almost a century, Manitoba francophones were used to the fact that everything connected to laws and the courts took place in English.

It is hardly surprising that, after such a long time, the audience of the French version of legislative documents does not really feel comfortable. A series of dynamic measures is therefore required to renew the construction of the French version of bilingual legislation to enable more effective communication with its audience and to better attain the constitutional objective of equal access to laws.

In this article, I shall first discuss the sociohistorical background forming the substance of the constitutional norm of legislative bilingualism 
célèbre affaire Forest ${ }^{4}$. Ainsi, pendant près d'un siècle, les francophones du Manitoba ont été habitués à ce que tout ce qui touche aux lois et aux tribunaux se passe en anglais.

Après une période aussi longue, il n'est pas étonnant que l'auditoire de la version française des textes de nature législative ne s'y sente pas véritablement chez soi. Un train de mesures énergiques s'impose donc pour renouveler la conception ou la facture du texte français de la législation bilingue afin qu'il permette davantage une communication réelle avec ses destinataires et que l'objectif constitutionnel d'égalité d'accès aux lois soit en conséquence mieux atteint.

Dans le cadre du présent article, j’aborderai dans un premier temps les faits socio-historiques qui servent de toile de fond, d'une part, à la norme constitutionnelle de bilinguisme législatif au Manitoba et, d'autre part, au besoin d'une réorientation de ses méthodes d'application. Après cette mise en situation, j'examinerai la portée de cette norme constitutionnelle et les moyens conventionnels susceptibles d'être employés pour tenter de la mettre en œuvre. En dernier lieu, je proposerai un certain nombre de mesures de rattrapage destinées à atténuer les conséquences de l'hiatus de 90 ans évoqué ci-dessus et à assurer que, sur le plan de son mode d'expression, la version française de la législation bilingue soit le mieux possible adaptée au public qu'elle vise.

\section{RAPPEL SOCIO-HISTORIQUE}

\section{A) Présence française dans l'Ouest canadien dès le XVIII ${ }^{\mathrm{e}}$ siècle}

À compter de 1731, La Vérendrye et ses fils explorent la partie méridionale des Prairies et se rendent jusqu'aux Rocheuses. Durant cette même période, les Français installent dans les Prairies un réseau de forts qui leur permettent de se livrer à la traite des fourrures avec les autochtones. En 1755, peu avant qu'éclate la guerre de Sept Ans, les Français quittent la région des Prairies jusqu'à la fin du régime français.

\section{B) Présence des voyageurs et naissance de la nation métisse}

Dès le début du régime anglais, des hommes d'affaires anglais et écossais fondent à Montréal la Compagnie du Nord-Ouest pour exploiter le marché des fourrures dans la vaste région située à l'ouest des Grands lacs. La Compagnie du NordOuest exercerait donc ses activités dans le territoire précédemment occupé par les Français dans la région des Prairies.

Pour assurer le transport des fourrures de la région des Prairies à Montréal, la Compagnie du in Manitoba on the one hand, and the need to redirect its application, on the other hand. Next, I shall examine the scope of this constitutional norm and conventional methods likely to be used for its implementation. Lastly, I shall propose a certain number of remedies to counter the effects of 90 years of English legislative unilingualism and to ensure that, in its mode of expression, the French version of bilingual legislation is optimally adapted to its target audience.

\section{SOCIO-HISTORICAL BACKGROUND}

\section{(A) French presence in the Canadian West from the 18th century}

As of 1731, La Vérendrye and his sons were exploring the southern regions of the Prairies, and even reached the Rockies. During this period, the French established a network of forts on the Prairies to trade with the native people. In 1755, shortly before the Seven Years War, the French left the Prairies, not to return until after the time of the French regime.

\section{(B) Presence of the voyageurs and birth of the Métis nation}

Early in the English regime, English and Scottish businessmen established the Northwest Company in Montreal to exploit the fur market in the vast region west of the Great Lakes. The Northwest Company thus operated in Prairie territory previously occupied by the French.

To ensure the transportation of furs from the Prairies to Montreal, the Northwest Company employed canoers known as voyageurs. As voyageurs were recruited mainly from towns and villages along the St. Lawrence River, most were Frenchspeaking. Given their important role in the fur trade, French naturally remained the language of trade.

Moreover, it often happened that voyageurs married native women. In addition to the strictly emotional advantages of these unions, voyageurs established improved business ties with Indian tribes and could rely on the invaluable support of their wives to survive during the harsh winters. Such widespread marriage between white men and native women gave birth to the Métis nation. When Rupert's Land was ceded to the government of Canada in 1870, the Métis, mostly Frenchspeaking and Catholic, comprised the vast majority of the population of the Prairies. 
Nord-Ouest faisait appel à des canotiers connus sous le nom de "voyageurs». Or, la compagnie recrutait principalement ses voyageurs dans les villes et villages situés le long du fleuve Saint-Laurent. Le plus grand nombre des voyageurs étaient donc d'expression française et, vu le rôle capital qu'ils jouaient dans le commerce des fourrures, le français est tout naturellement demeuré la langue de ce commerce.

En outre, il arrivait souvent que les voyageurs marient des femmes autochtones. En dehors des avantages strictement émotifs de ces unions, les voyageurs établissaient de meilleurs rapports commerciaux avec les tribus indiennes et pouvaient compter sur le précieux soutien de leurs femmes pour survivre pendant la dure saison de l'hiver.

Ces unions à large échelle entre des hommes blancs et des femmes autochtones ont donné naissance à la nation métisse.

Au moment de la cession de la terre de Rupert au gouvernement du Canada en 1870, les Métis constituaient la vaste majorité de la population dans les Prairies et la plupart d'entre eux étaient d'expression française et catholiques.

\section{C) Garanties constitutionnelles ou législatives accordées à la fin du $\mathrm{XIX}^{\mathrm{e}}$ siècle aux francophones de l'Ouest canadien en matière linguisti- que et religieuse}

Les francophones du Canada ont toujours perçu la fédération canadienne comme étant le résultat d'un pacte solennel conclu entre les deux peuples fondateurs.

Le régime de protection de la minorité canadienne-française incorporé dans la Loi constitutionnelle de $1867^{5}$ (l'ancien "Acte de l'Amérique du Nord-Britannique») s'articule autour de deux grands axes principaux, à savoir, d'une part, la protection de la confessionnalité des écoles prévue à l'article 93 et, d'autre part, le bilinguisme parlementaire, législatif et judiciaire au sein de l'État fédéral et de l'État provincial québécois prévu à l'article 133.

Il est important de rappeler que les pères de la Confédération ont élaboré les garanties en matière de confessionnalité des écoles à une époque où la langue et la foi étaient indissociables et que, dans leur esprit, ces garanties visaient certainement à protéger la langue d'enseignement.

Au moment de l'entrée du Manitoba dans la fédération canadienne en 1870, les francophones de cette province ont pu faire incorporer dans la constitution provinciale (à savoir la Loi de 1870 sur le Manitoba) un régime de protection qui correspondait presque complètement à celui dont bénéficiaient les francophones du Québec.
(C) Constitutional or legislative guarantees granted at the end of the 19th century to Western Canadian francophones in linguistic and religious matters

The French-speaking citizens of Canada have always perceived the Canadian federation as the result of a formal pact between the two founding peoples.

The scheme to protect the French-Canadian minority incorporated into the Constitution Act, $1867^{5}$ (formerly the British North America Act) hinged on two main factors: the protection of confessional schools under section 93, on one hand, and parliamentary, legislative, and judicial bilingualism within the federal and Quebec governments under section 133, on the other. It should be remembered that the Fathers of Confederation established guarantees for the confessionality of schools at a time when language and religion were inseparable. They no doubt intended these guarantees to protect the language of education.

When Manitoba entered the Confederation in 1870 , the francophones of that province succeeded in incorporating into the provincial constitution (i.e. the Manitoba Act, 1870) a protective regime almost entirely equivalent to that of the francophones of Quebec.

In 1875, the Parliament of Canada legislated a protective regime for confessional schools in the Northwest Territories, which at the time included the present-day provinces of Saskatchewan and Alberta. In 1877, again through legislation, the Parliament of Canada established a scheme for legislative and judicial bilingualism in the Territories. ${ }^{6}$

(D) Decrease in the demographic importance of francophones in Western Canada and the gradual erosion of their linguistic and religious rights at the turn of the 20th century

As already noted, francophones in the first 70 years of the 19th century comprised a significant proportion of the population of what is now Western Canada. However, with the arrival of the railway, and large numbers of anglophones from Ontario and immigrants from Eastern Europe, the demographic preponderance of francophones all but disappeared. Moreover, efforts to recruit FrenchCanadians from Quebec and New England largely failed.

Barely 15 or 20 years after the annexation of Rupert's Land to Canada, the English-Protestant elite of the Prairies no longer tolerated the protection afforded to the French-Catholic minority. In 1890, for example, the Greenway government of Manitoba unconstitutionally abolished confessional schools and parliamentary, legislative, and 
En 1875, le Parlement du Canada établissait par voie législative un régime de protection des écoles confessionnelles dans les Territoires du Nord-Ouest, qui englobaient alors les provinces de la Saskatchewan et de l'Alberta. En 1877, toujours par voie législative, le Parlement du Canada établissait, à l'égard des mêmes territoires, un régime de bilinguisme législatif et judiciaire ${ }^{6}$.

D) Baisse de l'importance démographique des francophones dans l'Ouest canadien et effritement graduel de leurs droits en matière linguistique et religieuse (au tournant du $\mathrm{XX}^{\mathrm{e}}$ siècle)

Comme je l'ai souligné, durant les 70 premières années du XIX $\mathrm{X}^{\mathrm{e}}$ siècle, les francophones représentaient une partie importante de la population dans l'Ouest canadien d'aujourd'hui.

Toutefois, avec l'arrivée du chemin de fer et d'un grand nombre d'Ontariens anglophones et d'immigrants de l'Europe de l'Est, le poids démographique des francophones a rapidement chuté. Par ailleurs, les efforts épiques déployés en vue de recruter des Canadiens français au Québec et en Nouvelle-Angleterre ont largement échoué.

À peine quinze ou vingt ans après l'annexion de la terre de Rupert au Canada, l'élite anglophone et protestante des Prairies n'acceptait plus le régime de protection conféré à la minorité française et catholique. En 1890, par exemple, le gouvernement Greenway du Manitoba abolissait inconstitutionnellement les écoles confessionnelles et le bilinguisme parlementaire, législatif et judiciaire. Dans les Territoires du Nord-Ouest, des tentatives étaient également faites pour amenuiser le plus possible les droits des francophones.

De fait, la question des francophones dans l'Ouest donne lieu à deux crises politiques majeures, l'une en 1896 au sujet du Manitoba et l'autre en 1905 au sujet de la Saskatchewan et de l'Alberta. Dans les deux cas, le gouvernement libéral de Sir Wilfrid Laurier doit tenter de réconcilier les intérêts opposés d'un Québec français et catholique et d'un Ontario anglais et protestant. Il faut malheureusement se rendre à l'évidence que les francophones de l'Ouest canadien sont essentiellement sacrifiés sur l'autel de l'équilibre précaire entre les deux provinces les plus populeuses du pays.

Par surcroît, les causes ${ }^{7}$ que la minorité française de l'Ontario a portées auprès des tribunaux britanniques au début du siècle ont révélé que les garanties en matière de confessionnalité ne comportaient aucune protection en ce qui a trait à l'enseignement en français, soit la langue que parlait la plupart des membres du groupe catholique. Ainsi, sur le plan de la langue, la protection de la confessionnalité des écoles s'est avérée un mirage, un coup d'épée dans l'eau. judicial bilingualism. Attempts were also made in the Northwest Territories to erode the rights of francophones.

The issue of francophones in the West gave rise to two major political crises: one in 1896 on the subject of Manitoba and the other in 1905 on the subject of Saskatchewan and Alberta. In both cases, the Liberal government of Sir Wilfrid Laurier attempted to reconcile the opposing interests of French-Catholic Quebec and English-Protestant Ontario. Unfortunately, it cannot be denied that, basically, the francophones of Western Canada were sacrificed to a precarious equilibrium between the two most populous provinces in the country. Moreover, the cases ${ }^{7}$ brought before the British courts by the French minority of Ontario at the beginning of the century demonstrated that guarantees in matters of confessionality did not afford protection for education in French, the language spoken by the majority of the Catholic group. Thus, on the linguistic level, protection of the confessionality of schools was but a mirage.

Like other minority francophone groups in Canada, the francophones of Western Canada experienced a "dark age" during which French schooling was to all intents and purposes forbidden, and parliamentary, legislative, and judicial bilingualism was limited to federal and Quebec institutions.

\section{(E) Linguistic and cultural status quo in closed homogenous societies in the early to middle $20^{\text {th }}$ century}

Their rights trampled, Western francophones managed to retain their language and culture by living in homogenous French-Canadian enclaves, often rural and cut off from the outside world, within which the Catholic clergy played a major role, in both the spiritual sphere and the worldly sphere (teaching, health and social services). However, outside these enclaves, English prevailed, and all who settled there were subject to enormous assimilating forces.

\section{(F) Post-war acceleration of assimilation attributable to urbanization and advances in telecommunications, in particular, television}

In the post-war years, many small farmers abandoned the land and migrated to the city. They took jobs in areas where English was the sole working language. Many other factors contributed to make urban francophone enclaves such as St. Boniface in Manitoba and St. Albert in Alberta progressively more vulnerable to external influences. In the country, as well as in the city, the television revolution made its way into almost every household- 
À l'instar des autres francophones en situation minoritaire au Canada, les francophones de l'Ouest canadien ont donc connu une période de «grande noirceur» au cours de laquelle l'enseignement en français était à toutes fins utiles interdit et où le bilinguisme parlementaire, législatif et judiciaire se limitait dans les faits aux institutions fédérales et québécoises.

E) Maintien linguistique et culturel dans des milieux homogènes fermés sur eux-mêmes (début et milieu du $\mathrm{XX}^{\mathrm{e}}$ siècle)

Leurs droits étant bafoués, les francophones de l'Ouest canadien arrivent à conserver leur langue et leur culture en vivant dans des enclaves canadiennes-françaises très homogènes et essentiellement coupées du monde extérieur (souvent rurales), au sein desquelles le clergé catholique joue un rôle prépondérant dans le domaine spirituel comme dans le domaine temporel (enseignement, services de santé et services sociaux).

Toutefois, en dehors de ces enclaves, l'anglais est roi et maitre et quiconque s'y établit s'expose à de très grandes forces assimilatrices.

F) Accélération du phénomène d'assimilation attribuable à l'urbanisation et aux progrès en matière de télécommunications (notamment à l'avènement de la télévision) [durant l'après-guerre]

Durant l'après-guerre, bon nombre de petits agriculteurs abandonnent la terre pour aller s'installer en ville et prendre des emplois dans des milieux où l'anglais est la seule langue de travail. Divers autres facteurs font en sorte que les enclaves francophones situées en milieu urbain (comme Saint-Boniface au Manitoba et Saint-Albert en Alberta) deviennent progressivement plus perméables aux influences de l'extérieur. Par ailleurs, autant en ville qu'à la campagne, l'invention révolutionnaire que constitue la télévision entre dans presque tous les foyers, et ce, en anglais seulement. Ainsi, l'anglais se met graduellement à jouer un rôle de plus en plus marqué dans la vie quotidienne des gens. Le français est essentiellement relégué à la vie familiale et religieuse.

\section{G) Revitalisation des collectivités francophones minoritaires (à compter des années 1960)}

Au cours des années 1960, le sort réservé aux minorités francophones à l'échelle du pays a renforcé la thèse des nationalistes québécois selon laquelle «hors du Québec, point de salut». Pour combattre le regain spectaculaire qu'a connu le mouvement nationaliste québécois à l'époque de la révolution tranquille, l'État fédéral s'est senti obligé d'interve- in English only. Thus, English gradually began to play a larger role in people's daily lives. French was, for the most part, relegated to family and religious life.

\section{(G) Revitalization of francophone minorities since the $1960 \mathrm{~s}$}

During the 1960s, the fate of francophone minorities across the country reinforced the "no hope outside Quebec" thesis of Quebec nationalists. To combat the spectacular resurgence of Quebec nationalist feeling during the Quiet Revolution, the federal government was forced to intervene to acknowledge the bilingual nature of the whole country and to revitalize francophone minority groups.

I shall paint a general picture of the national expansion of bilingualism, which began at the end of the 1960s, followed by the gains made in Manitoba since that time.

\section{National expansion of bilingualism}

The Official Languages Act ${ }^{8}$ in 1969 acknowledged the principle of official bilingualism at the federal level and for the first time forced the federal civil service, as opposed to parliamentary and judicial institutions, to provide bilingual services. In the wake of this new law, considerable progress was made in bilingualism throughout the country in the 1970s and 1980s.

At the federal level, the Canadian Charter of Rights and Freedoms ${ }^{9}$ constitutionalized the principle of provision of bilingual services by the federal administration, and the Official Languages $A c t^{10}$ in 1988 provided the method for implementing this new constitutional guarantee. At the provincial and territorial levels, bilingualism in legislative, judicial, and administrative institutions has also made significant gains. Examples are the adoption of an official languages act in New Brunswick $^{11}$ and the constitutionalization of linguistic rights for the citizens of that province, ${ }^{12}$ the second wind given to legislative and judicial bilingualism in Manitoba as a result of the Forest case, the adoption of a law on French language services in Ontario, ${ }^{13}$ and official language laws in the Northwest Territories ${ }^{14}$ and the Yukon. ${ }^{15}$

Where education in the minority language is concerned, a constitutional instrument, the Canadian Charter of Rights and Freedoms, has for the first time recognized the right of speakers of the minority official language to educate their children in their language everywhere in the country. It should however be noted that most provinces and territories with an anglophone majority must be cajoled into fulfilling obligations freely agreed to regarding the education of the French-speaking minority. 
nir pour reconnaître le caractère bilingue de l'ensemble du pays et revitaliser les collectivités minoritaires francophones.

Je brosserai d'abord un tableau général du phénomène national d'essor du bilinguisme qui s'est amorcé à la fin des années 1960 et je traiterai ensuite des gains réalisés au Manitoba depuis lors.

\section{Phénomène national d'essor du bilinguisme}

La Loi sur les langues officielles ${ }^{8}$ de 1969 reconnaissait le principe du bilinguisme officiel au niveau de l'État fédéral et obligeait pour la première fois la fonction publique fédérale, par opposition aux institutions parlementaires et judiciaires, à fournir des services bilingues.

Dans la foulée de cette nouvelle loi, des progrès considérables se sont produits en matière de bilinguisme partout au pays pendant les années 1970 et 1980 .

Au niveau de l'État fédéral, la Charte canadienne des droits et libertés ${ }^{9}$ a constitutionnalisé le principe de la prestation de services bilingues par l'administration fédérale et la Loi sur les langues officielles ${ }^{10}$ de 1988 énonce les modalités de mise en œuvre de cette nouvelle garantie constitutionnelle.

$\mathrm{Au}$ niveau des provinces et territoires, le bilinguisme au sein des institutions législatives, judiciaires et administratives a également marqué des gains importants. Citons à titre d'exemple l'adoption d'une loi sur les langues officielles au Nouveau-Brunswick ${ }^{11}$ et la constitutionnalisation de droits linguistiques pour les citoyens de cette province $^{12}$, le souffle nouveau donné au bilinguisme législatif et judiciaire au Manitoba à la suite de l'affaire Forest, ainsi que l'adoption d'une loi sur les services en français en Ontario ${ }^{13}$ et de lois sur les langues officielles dans les Territoires du Nord-Ouest ${ }^{14}$ et au Yukon ${ }^{15}$.

Sur le plan de l'enseignement dans la langue de la minorité, la Charte canadienne des droits et libertés a pour la première fois reconnu aux minorités de la langue officielle, dans un texte constitutionnel, le droit de faire instruire leurs enfants dans leur langue partout au pays. Il faut cependant signaler que la plupart des provinces et territoires à majorité anglophone se sont fait tirer l'oreille pour se conformer aux obligations qu'ils ont pourtant acceptées de leur propre gré en ce qui a trait à l'enseignement destiné à la minorité de la langue française.

Soulignons enfin l'émergence du phénomène des écoles d'immersion depuis une vingtaine d'années. Il existe un nombre de plus en plus important d'anglophones qui sont capables de communiquer en français et sont sensibles aux aspirations linguistiques et culturelles des francophones.
Finally, we should mention the emergence of the immersion school phenomenon in the last twenty years. There is an increasing number of anglophones who are able to communicate in French and who are sensitive to the linguistic and cultural aspirations of francophones.

\section{Gains made in Manitoba during the past thirty years}

Significant progress has been made In Manitoba over the past thirty years or more, and the francophone community has obtained many of the infrastructures it needs to live and prosper in its own language. The following are some examples:

- French regained its place in education in 1970 , when it was recognized as the language of instruction in public schools on an equal footing with English;

- French schools have been administered by a francophone school board since 1994;

- all statutes and regulations are bilingual and the courts function in both French and English;

- the provincial government has adopted a policy on French language services;

- a network of dynamic organizations sees to the advancement of community projects;

- the special cachet of largely francophone communities serves as an asset to favour their economic development.

In spite of giant steps taken, we must not be lulled into complacency. Assimilation continues, and with respect to identity, many young people from francophone families and educated in French schools consider themselves bilingual Canadians of French origin, rather than French-Canadians, Franco-Manitobans, or simply francophones. ${ }^{16}$

\section{SCOPE OF THE CONSTITUTIONAL NORM OF BILINGUAL LEGISLATION}

As we have seen, the guarantees obtained by Manitoba francophones for parliamentary, legislative, and judicial bilingualism are contained in section 23 of the Manitoba Act, 1870. In 1890, twenty years after the province was created, the Greenway government persuaded the House to enact the The Official Language Act ${ }^{17}$ (note the use of the word "language" in the singular). This act was manifestly unconstitutional and the lower courts did not hesitate to invalidate it in the years that followed. ${ }^{18}$ However, the province did not appeal against the judgments rendered by the trial courts-it merely swept them under the carpet. Consequently, it was not until the late 1970s that the 


\section{Gains réalisés au Manitoba depuis une trentaine d'années}

Au Manitoba, sur une période d'un peu plus de trente ans, des gains importants sont réalisés et la collectivité francophone obtient bon nombre des infrastructures dont elle a besoin pour vivre et s'épanouir dans sa langue. Citons les exemples suivants:

- le français retrouve ses lettres de noblesse dans le domaine de l'éducation en 1970, en étant reconnu comme langue d'enseignement dans les écoles publiques sur un pied d'égalité avec l'anglais;

- les écoles françaises relèvent d'un conseil scolaire francophone depuis 1994;

- les lois et règlements sont bilingues et les tribunaux fonctionnent à la fois en français et en anglais;

- le gouvernement provincial s'est doté d'une politique sur les services en français;

- un réseau d'organismes dynamiques se chargent de faire avancer les dossiers de la collectivité;

- le cachet particulier des localités à forte concentration de francophones sert comme atout pour favoriser leur développement économique.

Malgré les pas de géant accomplis, il ne faut pas se bercer d'illusions. L'assimilation continue à faire ses ravages et, sur le plan identitaire, bien des jeunes issus de familles francophones et formés dans les écoles françaises se considèrent comme des Canadiens bilingues de souche ou d'origine française plutôt que comme des Canadiens français, des Franco-Manitobains ou des francophones tout court ${ }^{16}$.

\section{PORTÉE DE LA NORME CONSTITUTIONNELLE DE BILINGUISME LÉGISLATIF}

Comme nous l'avons vu, les garanties obtenues par les francophones du Manitoba en matière de bilinguisme parlementaire, législatif et judiciaire figurent à l'article 23 de la Loi de 1870 sur le Manitoba.

En 1890, soit vingt ans après la création de la province, le gouvernement Greenway fait adopter en chambre la loi intitulée "The Official Language $\mathrm{Act}^{17}$ » (notez que le mot «language» est bien utilisé au singulier et non au pluriel). Il s'agit d'une loi qui est manifestement inconstitutionnelle et que les tribunaux inférieurs n'ont d'ailleurs pas hésité à invalider au cours des quelques années qui ont suivi ${ }^{18}$. Toutefois, la province n'a pas interjeté appel des jugements rendus par les tribunaux de
Supreme Court of Canada was seized of the Forest case and that it declared The Official Language Act unconstitutional. After all that, Franco-Manitobans were still not in the clear-they were obliged to return several times to the Supreme Court to force the provincial government to act.

The 1985 Reference Re Manitoba Language Rights $^{19}$ declared the invalidity of 90 years' worth of unilingual statutes enacted by the Manitoba Legislative Assembly. ${ }^{20}$ In the early 1990s, the Société franco-manitobaine and the government of Manitoba returned to the Supreme Court for clarification of the orders-in-council, thanks to a direct access mechanism granted to them under the 1985 order resulting from the reference of that same year. ${ }^{21}$

Because of the strong similarities between the wording of s. 23 of the Manitoba Act, 1870 and s. 133 of the Constitution Act 1867 and various related provisions, Manitoba is virtually plugged into the case law that has developed in respect of similar linguistic obligations of the federal government and the provinces of New Brunswick, Quebec, and Saskatchewan. ${ }^{22}$ Section 23 of the Manitoba Act, 1870 provides for the following rights and obligations:

(a) the right to use either French or English in the debates and proceedings of the Manitoba Legislature;

(b) the obligation to enact, print, and publish acts of the Legislature in both French and English;

(c) the obligation to print and publish the records and journals of the Manitoba Legislature in both French and English;

(d) the right to use either French or English as the spoken language in matters before courts established by the Manitoba Legislature;

(e) the right to use either French or English as the written language for acts of procedure in matters before courts established by the Manitoba Legislature.

The cumulative effect of the court decisions rendered to date on legislation is as follows:

(a) Statutes passed by the Manitoba Legislature must, on pain of nullity, be enacted, printed, and published in French and English simultaneously.

(b) The following forms of delegated legislation are also subject to the obligation of bilingualism (with the exception of internal rules and directives):

(i) regulations made by Cabinet;

(ii) regulations made by groups of ministers;

(iii) ministerial orders; 
première instance et s'est contentée de les balayer sous le tapis.

Par conséquent, il faudra attendre jusqu'à la fin des années 1970 pour que la Cour suprême du Canada soit saisie du dossier dans l'affaire Forest et déclare inconstitutionnelle la loi intitulée "The Official Language Act». Les Franco-Manitobains n'en étaient pas pour autant rendus au bout de leurs peines et ont dû retourner à quelques reprises devant la Cour suprême pour forcer le gouvernement provincial à agir.

Ainsi, le Renvoi de 1985 sur les droits linguistiques au Manitoba ${ }^{19}$ déclare l'invalidité des lois unilingues adoptées par l'Assemblée législative du Manitoba pendant 90 ans $^{20}$. Au début des années 1990, la Société franco-manitobaine et le gouvernement du Manitoba sont retournés devant la Cour suprême pour obtenir des éclaircissements concernant les décrets, et ce, grâce au moyen de l'accès direct à la Cour que celle-ci leur avait accordé dans son ordonnance de 1985 qui découlait du renvoi de la même année ${ }^{21}$.

Étant donné la forte ressemblance entre le libellé de l'article 23 de la Loi de 1870 sur le Manitoba et celui de l'article 133 de la Loi constitutionnelle de 1867 et de diverses dispositions-sœurs, le Manitoba est en quelque sorte branché sur la jurisprudence linguistique élaborée à l'égard des obligations de même nature qui incombent à l'État fédéral et aux provinces du Nouveau-Brunswick, du Québec et de la Saskatchewan ${ }^{22}$.

Rappelons que l'article 23 de la Loi de 1870 sur le Manitoba prévoit les obligations et les facultés suivantes:

a) la faculté d'employer le français ou l'anglais dans les débats et travaux de l'Assemblée législative du Manitoba;

b) l'obligation d'adopter, d'imprimer et de publier en français et en anglais les lois de l'Assemblée législative du Manitoba;

c) l'obligation d'imprimer et de publier en français et en anglais les archives, les comptes rendus et les procès-verbaux ( records and journals») de l'Assemblée législative du Manitoba;

d) la faculté d'employer le français ou l'anglais à titre de langue orale dans les affaires dont sont saisis les tribunaux établis par l'Assemblée législative du Manitoba;

e) la faculté d'employer le français ou l'anglais à titre de langue de rédaction des actes de procédure découlant des affaires dont sont saisis les tribunaux établis par l'Assemblée législative du Manitoba.

Sur le plan de la législation, l'effet cumulatif des décisions judiciaires rendues jusqu'à maintenant est le suivant: (iv) regulations adopted by public agencies, and subject to approval by the Cabinet, a group of ministers, or a minister, to the extent that the approval in question is required for the regulation to take effect;

(v) rules of judicial and quasi-judicial tribunals; ${ }^{23}$

(vi) orders-in-council that are determined to be "legislative in nature" under the following criteria developed in the 1992 Reference Re Manitoba Language Rights ${ }^{24}$ and applied in Sinclair v. Québec (A.G.): ${ }^{25}$

With respect to form, sufficient connection is established... where the instrument is, pursuant to legislation, enacted by the government, or made subject to the approval of the government.

With respect to content and effect, the following are indicative of a legislative nature: the instrument embodies a rule of conduct; the instrument has the force of law; and the instrument applies to an undetermined number of persons.

(c) Documents incorporated by reference into legislation are themselves subject to the obligation of bilingualism, if they meet the following criteria developed in Quebec (A.G.) v. Collier $^{26}$ and the 1992 Reference Re Manitoba Language Rights:

(i) The primary instrument into which the document is incorporated has a legislative character, in accordance with criteria established for orders-in-council in the 1992 Reference Re Manitoba Language Rights;

(ii) The incorporation is a true incorporation in that the document is an integral part of the primary instrument as though reproduced therein (a clear example of true incorporation is found in Quebec (A.G.) v. Collier);

(iii) The Legislature does not have a bona fide purpose for incorporating the instrument without translation, it being understood that practically the only case in which the bona fide purpose exception may be successfully invoked is where the document is generated by an outside source, for example, another government ${ }^{27}$ or a non-governmental body. ${ }^{28}$

\section{CONVENTIONAL METHODS FOR DRAFTING BILINGUAL LEGISLATION}

We shall examine in turn the three principal methods used for drafting bilingual legislation in Canada.

\section{Translation in isolation}

In translation in isolation, the legislative text is drafted in the source language by a drafter and 
a) les lois votées par l'Assemblée législative du Manitoba doivent être adoptées, imprimées et publiées simultanément en français et en anglais, sous peine d'invalidité;

b) les formes de législation déléguée suivantes sont également assujetties à l'obligation de bilinguisme (à l'exception des règles et des directives de régie interne):

i) les règlements pris par le Conseil des ministres;

ii) les règlements pris par un groupe de ministres;

iii) les arrêtés établis par un ministre;

iv) les règlements pris par des organismes publics sous réserve de l'approbation du Conseil des ministres, d'un groupe de ministres ou d'un ministre, dans la mesure où l'approbation en cause est nécessaire avant l'entrée en vigueur des règlements;

v) les règles de procédure des tribunaux judiciaires et quasi judiciaires ${ }^{23}$;

vi) les décrets qui sont déterminés comme étant «de nature législative» en fonction des critères suivants qui ont été élaborés dans le Renvoi de 1992 sur les droits linguistiques au Manitoba $^{24}$ et appliqués dans l'arrêt Sinclair $c$. Procureur général du Québec ${ }^{25}$ :

En ce qui à trait à la forme, un lien suffisant entre l'Assemblée législative du Manitoba et le texte indique qu'il est de nature législative. Ce lien est établi lorsque le texte est adopté, en vertu de la loi, par le gouvernement ou assujetti à l'approbation du gouvernement;

En ce qui a trait au contenu et à l'effet, les éléments suivants indiquent la nature législative:

- le texte comprend une règle de conduite;

- le texte a force de loi;

- le texte s'applique à un nombre indéterminé de personnes;

c) les documents incorporés par renvoi dans les lois sont eux aussi assujettis à l'obligation de bilinguisme, s'ils répondent aux critères suivants qui ont été élaborés dans l'arrêt Procureur général du Québec c. Collier ${ }^{26}$ et dans le Renvoi de 1992 sur les droits linguistiques au Manitoba:

i) le texte primaire auquel le document est incorporé revêt un caractère législatif, selon les critères établis à l'égard des décrets dans le Renvoi de 1992 sur les droits linguistiques au Manitoba;

ii) l'incorporation est une incorporation véritable, c'est-à-dire que le document fait partie intégrante du texte primaire comme s'il y était reproduit (un exemple clair d'in- forwarded as a finished product to a translator. The translator prepares the text in the target language, often without knowledge of the underlying political, social, or case law reasons. The following is a succinct description of this method, which prevailed at the federal level until the late 1970s and is now considered obsolete.

\section{[Translation]}

However, the equal legal status of both texts was not often accompanied by an equal processing of the two versions. Until the end of the 1970s, the French version of federal legal texts was too often a merely servile translation of the English version.

In the vast majority of cases, the drafting of statutes was entrusted to anglophone drafters, trained in the Common law only, who carefully wrote in English before turning to translators for a French "translation."

It was difficult for the translators to produce quality texts in French: they were called upon at the end of the process only, their deadlines were ridiculously short, they had little contact with the authors of the English text, the relevant documents were not easily accessible, and they participated little or not at all in discussions between the drafters and the department's instructing officers. In short, they were expected to produce official French versions "in isolation." 29

\section{Translation in tandem with drafters}

Under the method of translation in tandem with drafters, the text is composed by a drafter in the source language until the text has sufficiently gelled. The translating team then comes on board and prepares the target language version, interacting with the drafter until the final version is produced. ${ }^{30}$ Naturally, these translations are superior to translations produced in isolation.

\section{Co-drafting}

The co-drafting method was implemented in the late 1970 s by the federal government ${ }^{31}$ to solve the problems of translation in isolation, and was adopted by the government of New Brunswick ${ }^{32}$ in the 1980s. The following are the key elements of the origin and method of co-drafting by the federal government.

[Translation]

In his 1976 annual report, the Commissioner of Official Languages concluded that, to better comply with the spirit and letter of the Official Languages Act (federal statute enacted in 1969 and replaced in 1988) the Department of Justice should make major changes in its method of producing the French version of federal laws. In his opinion, French was being treated as the poor cousin and immediate remedial action was necessary. 
corporation véritable se trouve dans l'arrêt Procureur général du Québec c. Collier);

iii) le législateur ne dispose pas d'un motif légitime pour incorporer le texte sans le traduire, étant entendu que l'exception du motif légitime pourra être invoquée avec succès presque seulement dans le cas des documents émanant de sources extérieures, par exemple d'un autre gouvernement ${ }^{27}$ ou d'un organisme non gouvernemental ${ }^{28}$.

\section{MÉTHODES CONVENTIONNELLES DE RÉDACTION LÉGISLATIVE BILINGUE}

Nous examinerons à tour de rôle chacune des trois principales méthodes de rédaction législative bilingue en usage au Canada.

\section{Traduction en vase clos}

Dans le cadre de cette méthode, le texte de nature législative est élaboré par un ou une légiste dans la langue de départ pour ensuite être acheminé à la traduction, sous forme de produit fini. Le traducteur ou la traductrice prépare alors la version du texte dans la langue d'arrivée, souvent sans connaître les raisons politiques, sociales et jurisprudentielles qui le sous-tendent. Voici une description à la fois succincte et percutante de cette méthode qui a eu cours au gouvernement fédéral jusqu'à la fin des années 1970 et qui est maintenant considérée comme dépassée.

L'égalité de statut juridique des deux versions linguistiques des lois fédérales n'a toutefois pas toujours correspondu à l'égalité de traitement des deux versions. En effet, jusque vers la fin des années soixante-dix, la version française des textes législatifs fédéraux n'était qu'une traduction, trop souvent servile, réalisée à partir de la version anglaise.

La rédaction des textes de loi était confiée à des légistes anglophones, formés en common law uniquement dans la vaste majorité des cas, qui rédigeaient leurs textes en anglais, avec le plus grand soin possible, avant de confier à des traducteurs la tâche d'en faire une "traduction» française.

Pour les traducteurs, il était difficile de produire des textes français de qualité puisqu'ils n'intervenaient qu'en bout de piste, que les délais qu'on leur imposait étaient le plus souvent ridiculement courts, qu'ils avaient très peu de contacts avec l'auteur du texte anglais, que les documents pertinents étaient peu accessibles et qu'ils participaient peu ou pas du tout aux discussions entre les légistes et les chargés de projet des ministères. Bref, il leur était demandé de produire une version française officielle «en vase clos $»^{29}$.
The Department of Justice took the Commissioner's recommendations to heart. It quickly entrusted a working group with the study of how, in various bilingual and multilingual countries, normative instruments were drafted. As none of the existing methods seemed to fit the Canadian situation, the working group proposed a hitherto unknown drafting system subsequently called codrafting.

The new drafting system was implemented in 1978. Under this system, two drafters, one of whom is a francophone usually trained in the Civil law, and the other an anglophone usually trained in the Common law, are assigned the task of drafting federal legislation. Both drafters, or codrafters, have access to the same information, participate in discussions with the sponsoring department's instructing officers, establish the plan for the legislative instrument together, and separately draft their own language version. Each is invited to critique the text of his or her codrafter, and each ensures that the co-drafter's text is fully compatible with his or her own. ${ }^{33}$

In short, the goal is to produce, with the same care, two original, authentic versions. ${ }^{34}$

\section{REMEDIAL ACTION}

\section{(A) Necessity}

To illustrate, I will recount a short anecdote. Seven or eight years ago, the manager of a credit union asked me to translate a draft contract from English to French and invited me to participate in a meeting of the committee that was examining the project in question. I proceeded to translate, using the French legislative drafting techniques I had learned earlier in my career when I translated legislation for the Manitoba government. For example, I changed the presentation of the ideas in the English text and followed a pattern of moving from general to specific. Where applicable, I stated the principle before the exceptions, and in the case of enumerations, I presented the generic element before the often numerous specific elements. I must say that I was rather proud of having produced a text that was true to the essence of the French language. However, at the meeting, the manager of the credit union read a few key passages of the French version of the draft contract and exclaimed, to my great surprise, "Damn, this legal French is hard!”

This experience allowed me to understand emotionally what I already knew intellectually, but had not admitted: neither one of the bilingual legislative drafting methods described above lend themselves, without considerable change, to the 


\section{Traduction en tandem avec les légistes}

Dans le cadre de cette méthode, le texte de nature législative est élaboré par un ou une légiste dans la langue de départ jusqu'à ce qu'il atteigne un niveau suffisant de cristallisation. L'équipe de traduction entre alors en scène et prépare la version du texte dans la langue d'arrivée en ayant l'occasion d'interagir avec le ou la légiste jusqu'à ce qu'il revête sa forme finale ${ }^{30}$.

Les traductions produites à l'aide de cette méthode sont bien sûr d'une qualité nettement supérieure à celle des traductions faites en vase clos.

\section{Corédaction}

Visant à combler les lacunes de la traduction en vase clos, la méthode de la corédaction a été mise au point par le gouvernement fédéral ${ }^{31}$ à la fin des années 1970 et a été adoptée par le gouvernement du Nouveau-Brunswick ${ }^{32}$ au cours des années 1980. Voici les éléments-clés de la genèse et du mode de fonctionnement de la corédaction au sein du gouvernement fédéral:

Dans son rapport annuel de 1976, le Commissaire aux langues officielles en est venu à la conclusion que le ministère de la Justice devait apporter de sérieuses modifications à sa façon de réaliser la version française des lois fédérales, afin de mieux respecter l'esprit et la lettre de la Loi sur les langues officielles (loi du Parlement canadien adoptée en 1969, puis remplacée en 1988). À son avis, le français était traité en parent pauvre et il fallait à tout prix remédier à la situation dans les meilleurs délais.

Le ministère de la Justice a pris très au sérieux les recommandations du Commissaire aux langues officielles. Il a rapidement chargé un groupe de travail d'étudier comment, dans les divers pays bilingues ou multilingues, on s'y prenait pour rédiger les textes normatifs. Aucune des méthodes existantes ne semblant convenir tout à fait à la situation canadienne, le groupe de travail a proposé que l'on mette en place un système rédactionnel inédit que l'on a par la suite qualifié de "corédaction».

C'est en 1978 qu'on a commencé à mettre en place ce nouveau système de rédaction. En vertu de ce système, on confie à deux légistes - un francophone, normalement formé en droit civil, et un anglophone, normalement formé en common law - le soin de rédiger les mesures législatives fédérales. Les deux légistes, ou corédacteurs, ont accès à la même information, participent tous deux aux dis- creation of a French text that ensures real communication with a francophone readership that has been subjected to 90 years of English unilingualism in the field of law.

Let me make one thing clear: my purpose is not to criticize the drafters and translators of laws. They do very good work in the context of their relatively narrow mandate and given the limited resources available to them. Rather, I imagine remedial action that could be taken in an ideal world to correct past injustices.

Manitoba francophones tend to avail themselves of French language legal services only when these are actively offered, are supplied in the natural course of events, and constitute an integral part of their daily lives. In my opinion, the measures should be based on the assumption that the same is true for legislative texts and that these will be read and understood if they conform to people's reality. I therefore propose that measures be taken on the following three levels:

- codification of laws;

- simplification of legislation;

- clarification of the law in French.

\section{(B) Codification of laws}

Legislation in Manitoba, as in other Canadian jurisdictions, is composed of a more or less coherent body of law dealing with relatively narrow issues. An example is family legislation, which includes the following statutes inter alia:

- The Adoption Act (Loi sur l'adoption)

- The Change of Name Act (Loi sur le changement de nom)

- The Child and Family Services Act (Loi sur les services à l'enfant et à la famille)

- The Child Custody Enforcement Act (Loi sur l'exécution des ordonnances de garde)

- The Dependants Relief Act (Loi sur l'aide aux personnes à charge)

- The Domestic Violence and Stalking Prevention, Protection and Compensation Act (Loi sur la violence familiale et la protection, la prévention et l'indemnisation en matière de harcèlement criminel)

- $\quad$ The Domicile and Habitual Residence Act (Loi sur le domicile et la résidence habituelle)

- The Family Maintenance Act (Loi sur l'obligation alimentaire)

- The Homesteads Act (Loi sur la propriété familiale)

- The Law of Property Act (Loi sur les droits patrimoniaux)

- The Reciprocal Enforcement of Maintenance Orders Act (Loi sur la réciprocité d'exécution des ordonnances alimentaires) 
cussions avec les chargés de projet du ministère parrain, établissent ensemble le plan du texte législatif, puis rédigent chacun leur version linguistique. Chacun est invité à critiquer le texte de son corédacteur et doit s'assurer que le texte de son collègue est tout à fait compatible avec le $\operatorname{sien}^{33}$.

En somme, l'objectif est de produire, avec le même soin, deux versions originales et authentiques $^{34}$.

\section{MESURES DE RATTRAPAGE}

\section{A) Nécessité de mesures de rattrapage}

Pour illustrer mon propos, je me permettrai de relater une courte anecdote. Il y a sept ou huit ans, le directeur d'une caisse populaire m'a demandé de traduire un projet de contrat de l'anglais vers le français et de participer à la réunion du comité chargé d'étudier le projet en question. J'ai donc établi une traduction en m'efforçant de suivre les techniques de rédaction législative française que j'avais apprises plus tôt dans ma carrière alors que j'étais traducteur de lois au gouvernement du Manitoba. Par exemple, j'ai modifié l'agencement des idées adopté dans le texte anglais pour suivre la démarche allant du général au particulier. Ainsi, là où il y avait lieu, j'ai énoncé le principe avant les exceptions et, dans les énumérations, j'ai fait figurer l'élément générique avant les éléments spécifiques parfois nombreux. Je dois dire que j'étais plutôt fier d'avoir produit un texte véritablement conforme au génie de la langue française. Or, à la réunion du comité, le directeur de la caisse a lu quelques passagesclés de la version française du projet de contrat et s'est ensuite exclamé, à mon grand étonnement: «maudit que c'est dur le français légal!»

Cette expérience m'a permis de comprendre viscéralement ce que je savais déjà intellectuellement mais n'osais pas m'avouer: ni l'une ni l'autre des méthodes de rédaction législative bilingue décrites ci-dessus ne se prête, sans faire l'objet d'adaptations considérables, à l'élaboration d'un texte français qui assure une communication réelle avec un auditoire francophone ayant vécu 90 ans d'unilinguisme anglais dans le domaine du droit.

Qu'on me comprenne bien: mon but n'est pas de critiquer les légistes et les traducteurs de lois. Ces gens font très bien leur travail, dans le cadre du mandat relativement étroit qui leur est confié et au moyen des ressources limitées dont ils disposent. J'entends plutôt rêver un peu et imaginer les mesures de rattrapage qui pourraient être prises, dans un monde idéal, pour corriger les injustices du passé.

Les francophones du Manitoba ont tendance à se prévaloir des services en français dans le domaine
- The Marital Property Act (Loi sur les biens matrimoniaux)

- $\quad$ The Marriage Act (Loi sur le mariage)

- The Married Women's Property Act (Loi sur les biens de la femme mariée)

- The Parental Responsibility Act (Loi sur la responsabilité parentale)

- The Parents' Maintenance Act (Loi sur l'obligation alimentaire des enfants)

- The Vital Statistics Act (Loi sur les statistiques de l'état civil)

- Court of Queen's Bench Rules in family matters (règles de la Cour du Banc de la Reine applicables aux instances en matière familiale)

I propose that, in each major area of the law, the existing statutes be merged into a small number (ideally one) forming a coherent whole, in which the legislative rules are stated in a logical (even educational) order and fundamental notions are clearly explained. ${ }^{35}$

This would not involve a civilist or Roman type of codification resulting in a Manitoba civil code. Rather, I mean a codification of the type that was achieved in the area of security on personal property in the 1970s in most Common law jurisdictions of Canada, allowing the consolidation and rationalization of rules applying to a large number of different types of security on personal property that had previously existed.

\section{(C) Simplification of legislation}

Legislation should be the focus of a massive effort to simplify both vocabulary and syntax. Drafters and authors already unanimously agree on the need for the legislature to use, both in French and in English, simple and correct language that the average person can understand. I shall limit myself to referring the reader to the abundant literature on the subject of readability. ${ }^{36}$

\section{(D) Clarification of the law in French}

In addition to measures on the drafting of legislative documents, it appears essential to me that the francophone population should be offered a wide range of activities to clarify the law in French. The purpose of such activities would be, in particular, to send the message that it is possible to discuss legal issues in French and to give people the opportunity to become familiar with French legal terminology.

\section{CONCLUSION}

In this article, I have presented the socio-political factors that call for in-depth reform of the mode of expression used in the legislative documents of Manitoba, and I have attempted to identify the 
du droit, dans les seuls cas où ceux-ci font l'objet d'une offre active, sont fournis de manière naturelle ou normale et constituent une partie intégrante de leur vécu quotidien. À mon avis, les interventions à effectuer doivent être définies en fonction du postulat qu'il en va de même pour les textes de nature législative et qu'ils seront lus et compris s'ils collent bien à la réalité des gens.

Je propose donc des interventions sur les trois plans suivants:

- la codification des lois;

- la simplification des lois;

- la vulgarisation du droit en français.

\section{B) Codification des lois}

$\mathrm{Au}$ Manitoba comme dans bien d'autres ressorts législatifs canadiens, le corpus législatif se compose d'une multitude de textes qui portent sur des questions relativement étroites et qui sont plus ou moins bien articulés les uns avec les autres. Citons à titre d'exemple le corpus en matière de droit familial, qui comporte entre autres les textes suivants:

- Loi sur l'adoption;

- Loi sur le changement de nom;

- Loi sur les services à l'enfant et à la famille;

- Loi sur l'exécution des ordonnances de garde;

- Loi sur l'aide aux personnes à charge;

- Loi sur la violence familiale et la protection, la prévention et l'indemnisation en matière de harcèlement criminel;

- Loi sur le domicile et la résidence habituelle;

- Loi sur l'obligation alimentaire;

- Loi sur la propriété familiale;

- Loi sur les droits patrimoniaux;

- Loi sur la réciprocité d'exécution des ordonnances alimentaires;

- Loi sur les biens matrimoniaux;

- Loi sur le mariage;

- Loi sur les biens de la femme mariée;

- Loi sur la responsabilité parentale;

- Loi sur l'obligation alimentaire des enfants;

- Loi sur les statistiques de l'état civil;

- règles de la Cour du Banc de la Reine applicables aux instances en matière familiale.

Je propose que, pour chaque grand domaine du droit, les diverses lois existantes soient fusionnées en un petit nombre de lois (idéalement une seule) qui forment un tout cohérent, dans lequel les règles législatives sont énoncées selon un ordre logique (voire pédagogique) et les concepts fondamentaux sont expliqués clairement ${ }^{35}$.

Il n'est pas question ici d'une codification de style civiliste ou romaniste qui déboucherait sur une espèce de Code civil du Manitoba. Il s'agit plutôt d'une codification comme celle qui s'est produite en matière de sûretés mobilières au cours des années 1970 dans la plupart des ressorts de common main avenues of such reform. Of course, the measures I favour would require significant funds; nevertheless, to the extent that the codification and simplification of laws would benefit the population as a whole, the reform I propose is perhaps not completely out of the question. However, if my challenge is not accepted, the French version of Manitoba legislation will be a monument to the failure of a noble but regrettably fruitless constitutional ideal.

\section{NOTES}

1. (Can.), 33 Vict., c. 3

2. [1985] 1 S.C.R. 721.

3. Ibid. at 739 .

4. [1979] 2 S.C.R. 1032.

5. (U.K.), 30 \& 31 Vict., c. 3

6. The history of the latter regime is explained in detail in R. v. Mercure, [1988] 1 S.C.R. 234.

7. See especially Ottawa Separate Schools Trustees v. Mackell, [1917] A.C. 62.

8. R.S.C. 1985 , c. O-3.

9. Part I of the Constitution Act, 1982, being Schedule B to the Canada Act 1982 (U.K.), 1982, c. 11.

10. R.S.C. 1985 (4th Supp.), c. 31.

11. Official Languages of New Brunswick Act, R.S.N.B. 1973, c. O-1.

12. Sections 16 to 23 and section 16.1 of the Canadian Charter of Rights and Freedoms.

13. French Language Services Act, S.O. 1986, c. 45.

14. Official Languages Act, R.S.N.W.T. 1988, c. O-1.

15. Languages Act, S.Y. 1988, c. 13.

16. J. Lafontant, "Les jeunes Franco-Manitobains et l'identité culturelle," Thèmes canadiens, issue devoted to duality and diversity, Summer 2000, 26-30.

17. S.M. 1890, c. 14.

18. Pellant v. Hébert (1981), 12 R.G.D. 242 (Man. S.C.), March 1892, and Bertrand v. Dussault (1977), 77 D.L.R. (3rd) 458 (Man. Co. Ct.), January 30, 1909.

19. Supra note 2 .

20. With regard to the Manitoba Legislature's difficulty in respecting the principle of parliamentary and legislative bilingualism immediately after the Supreme Court's ruling in the Reference, see Waite v. R. (1986), 25 D.L.R. (4th) 696, aff'd (1987), 47 Man. R. (2d) 247 (C.A.), and the following commentaries: H. Brun \& G. Tremblay, Droit constitutionnel, 3rd ed. (Cowansville, Que.: Yvon Blais, 1997) at 824; G. Jourdain, "L’article 23 sitôt revigoré, sitôt bafoué" (1986) 4:3 Télé-CLEF 16-17; G. Jourdain, "Le français à la législature du Manitoba: la Cour d'appel absout les gaffes de la province" (1987) 5:3 Télé-CLEF 14-16; A. Tremblay, "Les droits linguistiques (articles 16 à 22)," in 
law canadiens et qui a permis le regroupement et l'harmonisation des règles applicables au grand nombre de types différents de sûretés mobilières existant auparavant.

\section{C) Simplification des lois}

Les lois devraient faire l'objet d'un effort massif de simplification, à la fois sur les plans du vocabulaire et de la syntaxe. Il y a d'ailleurs déjà unanimité chez les légistes et les auteurs quant à la nécessité pour le législateur d'employer, en français comme en anglais, une langue simple et correcte que la personne moyenne est en mesure de comprendre. La doctrine étant abondante sur ce qu'il est convenu d'appeler la «lisibilité », je me limiterai à y renvoyer le lecteur ou la lectrice ${ }^{36}$.

\section{D) Vulgarisation du droit en français}

En plus des mesures touchant la rédaction même des textes de nature législative, il me paraît essentiel que le public francophone se voie offrir toute une gamme d'activités de vulgarisation juridique en français. Ces activités viseraient notamment à faire passer le message qu'il est possible de parler de questions juridiques en français et à donner l'occasion aux gens de se familiariser davantage avec la terminologie juridique de base en français.

\section{CONCLUSION}

Dans le présent article, j'ai présenté les facteurs socio politiques qui commandent une réforme en profondeur du mode d'expression employé dans les textes de nature législative au Manitoba et j'ai tenté de cerner les principaux axes que devrait suivre une telle réforme.

De toute évidence, les mesures que je préconise nécessiteraient le déblocage de fonds importants. Toutefois, dans la mesure où la codification et la simplification des lois seraient bénéfiques pour l'ensemble de la population, la réforme que je propose n'est peut-être pas complètement hors de question.

Quoi qu'il en soit, si le défi que je lance n'était pas relevé, la version française de la législation manitobaine constituera un monument à l'échec d'un idéal constitutionnel fort noble mais qui sera très regrettablement demeuré vain.

\section{NOTES}

1. L.R.C. (1985), appendice II, nE 8.

2. [1985] 1 R.C.S. 721.

3. Ibid., p. 739.

4. [1979] 2 R.C.S. 1032

5. L.R.C. (1985), appendice II, nE 5.

6. L'historique de ce dernier régime est expliqué en détail dans l'arrêt La Reine c. Mercure, [1988] 1 R.C.S. 234.
G.A. Beaudoin \& E.P. Mendes, eds., Charte canadienne des droits et libertés, 3rd ed. (Montreal: Wilson \& Lafleur, 1996) at 934.

21. [1985] 2 S.C.R. 347.

22. With regard to the possible scope of s. 23 of the Manitoba Act, 1870, see R. Teffaine, "Le champ d'application de l'article 23 de la Loi de 1870 sur le Manitoba" (1986) 4:1 Télé-CLEF 12-14.

23. The Supreme Court of Canada rendered judgment with respect to the forms of delegated legislation covered in sub-paragraphs (i) to (v) in Blaikie No. 2, [1981] 1 S.C.R. 312.

24. [1992] 1 S.C.R. 212.

25. [1992] 1 S.C.R. 579.

26. [1985] C.A. 559, aff'd [1990] 1 S.C.R. 260.

27. (1991), 4 O.R. (3d) 705 (C.A.).

28. P.W. Hogg, Constitutional Law of Canada, 3rd ed. (Toronto: Carswell, 1992) at 1208-1209, and J.M. Keyes, Executive Legislation (Toronto: Butterworths, 1992) at 273-276.

29. L. Levert, Le défi de la rédaction législative bilingue au Canada (Internet: www.ovea.net/ rijef/Templates/Lionel\%20Levert.htm 2000, last visited April 30, 2001).

30. For a description of how this method is used in Ontario, see M. Moisan, La réalisation de textes législatifs bilingues en Ontario (Internet: www.ovea.net/rijef/Templates/MOISAN.htm 2000, last visited April 30, 2001).

31. L. Levert, "Bijuridisme et bilinguisme législatifs: un enjeu et un pari” in G. Snow \& J. Vanderlinden, eds., Français juridique et science $d u$ droit (Brussels: Bruylant, 1995) 255; E. Didier, Langues et langages du droit: étude comparative des modes d'expression de la common law et du droit civil en français et en anglais (Montreal: Wilson \& Lafleur, 1990) at 323.

32. J. Keating, "La corédaction et l'expérience néobrunswickoise" in G. Snow \& J. Vanderlinden, eds., Français juridique et science du droit (Brussels: Bruylant, 1995) 203.

33. Moisan, supra note 29.

34. Levert, supra note 31 at 258.

35. For example, in property law, legislation resulting from such codification should clearly explain what is meant by property, real estate, and mortgage. At this time, despite a surfeit of texts on the subject, it is impossible to find a definition of the notion of mortgage that the average person can understand.

36. See generally N. Fernbach, La lisibilité dans la rédaction juridique au Québec (Ottawa: Plain Language Centre, Centre canadien de formation juridique, 1990); C. Mowat, A Plain Language Handbook for Legal Writers (Scarborough: Carswell, 1998); J.-C. Gémar, "Le discours législatif et le langage du droit: rédaction, style et texte juridiques" (1994) 25 R.G.D. 327; S. Krongold, "Writing Laws: Making them Easier to Understand" (1992) 24 R.D. Ottawa 495. 
7. Voir notamment l'arrêt Ottawa Separate Schools Trustees c. Mackell, [1917] A.C. 62.

8. L.R.C. (1985), chap. O-3.

9. Partie I de la Loi constitutionnelle de 1982, reproduite dans L.R.C. (1985), app. II, nE 44.

10. L.R.C. (1985), chap. 31 (4e supplément).

11. Loi sur les langues officielles du NouveauBrunswick, L.R.N.-B. (1973), chap. O-1.

12. Articles 16 à 23 et article 16.1 de la Charte canadienne des droits et libertés.

13. Loi sur les services en français, S.O. 1986, chap. 45.

14. Loi sur les langues officielles, L.R.T.N.-O. 1988, chap. O-1.

15. Loi sur les langues, L.Y. 1988, chap. 13.

16. Lafontant, Jean, «Les jeunes Franco-Manitobains et l'identité culturelle», Thèmes canadiens, numéro consacré à la dualité et à la diversité, été 2000, 26-30.

17. S.M. 1890, chap. 14.

18. Pellant c. Hébert, Cour suprême du Manitoba, mars 1892, (1981) 12 R.G.D. 242 et Bertrand c. Dussault, Cour de comté du Manitoba, 30 janvier 1909, (1977) 77 D.L.R. (3d) 458.

19. Voir note 2.

20. En ce qui concerne les difficultés que l'Assemblée législative du Manitoba a connues pour respecter le principe du bilinguisme parlementaire et législatif immédiatement après que la Cour suprême du Canada a rendu son avis dans le Renvoi, voir l'affaire Waite c. La Reine (1986), 25 D.L.R. (4th) 696, confirmé par (1987), 47 Man. R. (2d) 247 (C.A.) et les commentaires suivants: Brun, Henri et Tremblay, Guy, Droit constitutionnel, $3^{\mathrm{e}}$ édition, Cowansville, Éditions Yvon Blais, 1997, p. 824 ; Jourdain, Guy, «L'article 23 sitôt revigoré, sitôt bafoué» (1986), 4 Télé-CLEF n ${ }^{\circ} 3$, p. 16-17; Jourdain, Guy, «Le français à la législature du Manitoba: la Cour d'appel absout les gaffes de la province» (1987), 5 Télé-CLEF n $\mathrm{n}^{\circ}$ 3, p. 14-16; Tremblay, André, «Les droits linguistiques (articles 16 à 22)", dans Beaudoin, G.A. et Mendes, E.P. (dir.), Charte canadienne des droits et libertés, $3^{\mathrm{e}}$ édition, Montréal, Éditions Wilson \& Lafleur, 1996, p. 934.

21. [1985] 2 R.C.S. 347.

22. En ce qui concerne la portée possible de l'article 23 de la Loi de 1870 sur le Manitoba, voir Teffaine, Rhéal, «Le champ d'application de l'article 23 de la Loi de 1870 sur le Manitoba", (1986), 4 Télé-CLEF n ${ }^{\circ} 1$, p. 12-14.

23. La Cour suprême du Canada s'est prononcée à l'égard des formes de législation déléguée visées aux sous-alinéas i) à v) dans l'arrêt Blaikie $n^{\circ} 2$, [1981] 1 R.C.S. 312.

24. [1992] 1 R.C.S. 212.

25. [1992] 1 R.C.S. 579.

26. [1985] C.A. 559, confirmé par [1990] 1 R.C.S. 260.

27. (1991), 4 O.R. (3d) 705 (C.A.).

\section{REFERENCES}

\section{Legislation}

Canadian Charter of Rights and Freedoms, Part I of the Constitution Act, 1982, being Schedule B to the Canada Act 1982 (U.K.), 1982, c. 11.

Constitution Act, 1867 (U.K.), 30 \& 31 Vict., c. 3. Manitoba Act, 1870 (Can.), 33 Vict., c. 3

Languages Act, S.Y. 1988, c. 13.

Official Languages Act, R.S.C. 1985 (4th Supp.), c. 31.

Official Languages Act, R.S.C. 1985, c. O-3.

Official Languages Act, R.S.N.W.T. 1988, c. O-1.

Official Languages Act of New Brunswick Act, R.S.N.B. 1973, c. O-1.

French Language Services Act, S.O. 1986, c. 45.

The Official Language Act, S.M. 1890, c. 14.

Cases

Bertrand v. Dussault (1977) 77 D.L.R. (3rd) 458

(Man. Co. Ct.), January 30, 1909.

Blaikie No. 2, [1981] 1 S.C.R. 312.

R. v. Mercure, [1988] 1 S.C.R. 234.

Ottawa Separate Schools Trustees v. Mackell, [1917] A.C. 62.

Pellant v. Hébert (1981), 12 R.G.D. 242 (Man. S.C.), March 1892.

Manitoba (A.G.) v. Forest, [1979] 2 S.C.R. 1032.

Quebec (A.G.) v. Collier, [1985] C.A. 559, aff'd [1990] 1 S.C.R. 260.

Reference Re Manitoba Language Rights, [1985] 1 S.C.R. 721.

Re Manitoba Language Rights Order, [1985] 2 S.C.R. 347.

Reference Re Manitoba Language Rights, [1992] 1 S.C.R. 212.

Sinclair v. Quebec (A.G.), [1992] 1 S.C.R. 579.

Waite v. R. (1986), 25 D.L.R. (4th) 696, aff'd (1987), 47 Man. R. (2d) 247 (C.A.).

\section{Secondary materials}

Socio-historical reality

(I) воокs

CArrière, L. (1981): Les Français dans les Pays d'en Haut, Toronto, McGraw-Hill Ryerson.

Frémont, D. (1980): Les Français dans l'Ouest canadien, Saint-Boniface, Éditions du Blé.

- (1948): Les Métis de l'Ouest canadien, Ottawa, Société royale du Canada.

Giraud, M. (1984): Le Métis canadien, SaintBoniface, Éditions du Blé.

Jaenen, C. (1976): Regards sur les Franco-Manitobains, Winnipeg, University of Winnipeg Press.

Lingard, C. (1946): Territorial Government in Canada - The Autonomy Question in the Old North-West Territories, Toronto, University of Toronto Press.

MacEwan, G. (1984): Les Franco-Canadiens dans l'Ouest, Saint-Boniface, Éditions des plaines.

Morton, A. (1973): A History of the Canadian West to $1870-71,2$ nd édition, Toronto, University of Toronto Press. 
28. Hogg, Peter, Constitutional Law of Canada, $3^{\mathrm{e}}$ édition, Toronto, Carswell, 1992, p. 1208-1209, et Keyes, John M., Executive Legislation, Toronto, Butterworths, 1992, p. 273-276.

29. Levert, Lionel, Le défi de la rédaction législative bilingue au Canada, [En ligne], 2000. [www. ovea.net/rijef/Templates/Lionel \%20Levert. htm] (30 avril 2001).

30. Pour une description de l'utilisation de cette méthode en Ontario, voir: Moisan, Michel, La réalisation de textes législatifs bilingues en Ontario, [En ligne], 2000. [www.ovea.net/rijef/ Templates/MOISAN.htm] (30 avril 2001).

31. Levert, Lionel, «Bijuridisme et bilinguisme législatifs: un enjeu et un pari», dans Gérard Snow et Jacques Vanderlinden (dir.), Français juridique et science $d u$ droit, Bruxelles, Bruylant, 1995, p. 255 à 266; Didier, Emmanuel, Langues et langages du droit: étude comparative des modes d'expression de la common law et du droit civil en français et en anglais, Montréal, Wilson \& Lafleur, 1990, p. 323.

32. Keating, Judith, «La corédaction et l'expérience néo-brunswickoise », dans Gérard Snow et Jacques Vanderlinden (dir.), Français juridique et science $d u$ droit, Bruxelles, Bruylant, 1995, p. 203 à 217.

33. Voir l'article dont la référence est fournie à la note 29.

34. Voir la p. 258 de l'article de $\mathrm{M}^{\mathrm{e}}$ Lionel Levert qui est mentionné à la note 31 .

35. Par exemple, en matière de droit des biens, la ou les lois résultant de cette codification devraient expliquer clairement ce qu'on entend par un bien, un bien-fonds ou une hypothèque. À l'heure actuelle, malgré le foisonnement de textes dans ce domaine, il est impossible de trouver une définition du concept d'hypothèque que la personne moyenne serait en mesure de bien comprendre.

36. On pourra notamment consulter à ce sujet les ouvrages et les articles suivants: Fernbach, Nicole, La lisibilité dans la rédaction juridique au Québec, Ottawa, Centre de promotion de la lisibilité, Centre canadien de formation juridique, 1990, 128 p.; Mowat, Christine, A Plain Language Handbook for Legal Writers, Scarborough, Carswell, 1998; Gémar, JeanClaude, "Le discours législatif et le langage du droit: rédaction, style et texte juridiques ", (1994) 25 Revue générale de droit, 327-345; Krongold, Susan, «Writing Laws: Making them Easier to Understand», (1992) 24 Revue de droit d'Ottawa, 495-581.

\section{RÉFÉRENCES}

\section{Textes constitutionnels et législatifs}

Charte canadienne des droits et libertés, partie I de la Loi constitutionnelle de 1982, reproduite dans L.R.C. (1985), app. II, no 44.
Painchaud, R. (1986): Un rêve français dans le peuplement de la Prairie, Saint-Boniface, Éditions des plaines.

Prud'homme, L.-A. (1904): L'élément français au Nord-Ouest: voyageurs canadiens français et Métis, 1763-1870, Montréal, Compagnie de la Revue canadienne.

(II) ARTICLES

Aunger, E. A. (1993): "The Decline of a FrenchSpeaking Enclave: A Case Study of Social Contact and Language Shift in Alberta," 25 Canadian Ethnic Studies 65-83.

Lafontant, J. (2000): "Les jeunes Franco-Manitobains et l'identité culturelle," Thèmes canadiens, numéro consacré à la dualité et à la diversité, 26-30.

Pelletier, B. (1994): “Les rapports de force entre les majorités et les minorités de langue officielle au Canada," 24 R.D.U.S. 256-292.

\section{Language rights}

(I) BоOKS

Bastarache, M. et al. (1987): Language Rights in Canada, Cowansville, Éditions Yvon Blais.

Bastarache, M. et al. (1986): Les droits linguistiques au Canada, Cowansville, Éditions Yvon Blais.

BLAY, J. (1987): L’article 23: les péripéties législatives et juridiques du fait français au Manitoba, 18701986, Saint-Boniface, Éditions du Blé, 392 p.

Brun, H. et G. Tremblay (1997): Droit constitutionnel, 3rd ed., Cowansville, Éditions Yvon Blais.

Canada, Rapport de la Commission royale d'enquête sur le bilinguisme et le biculturalisme, livre I, Les langues officielles, Ottawa, Imprimeur de la Reine, 1967 (rapport Laurendeau-Dunton).

Foucher, P. (1985): Constitutional Language Rights of Official-Language Minorities in Canada, Ottawa, Canadian Law Information Council.

- (1985): Les droits scolaires constitutionnels des minorités de langue officielle du Canada, Ottawa, Conseil canadien de la documentation juridique.

Hogg, P. (1992): Constitutional Law of Canada, 3rd ed., Toronto, Carswell.

Keyes, J. M. (1992): Executive Legislation: Delegated Law Making by the Executive Branch, Toronto, Butterworths.

LÉGER, Sylvie, dir. (1995): Les droits linguistiques au Canada: collusions ou collisions, Ottawa, Centre canadien des droits linguistiques.

Martel, A. (1991): Les droits scolaires des minorités de langue officielle au Canada: de l'instruction à la gestion, Ottawa, Commissariat aux langues officielles.

Pupier, P. et J. Woehrling (1989): Langue et droit: Actes du premier congrès de l'Institut international de droit linguistique comparé, Montréal, Wilson \& Lafleur. 
Loi constitutionnelle de 1867, L.R.C. (1985), appendice II, $\mathrm{n}^{\circ} 5$.

Loi de 1870 sur le Manitoba, L.R.C. (1985), appendice II, $\mathrm{n}^{\circ} 8$.

Loi sur les langues, L.Y. 1988, chap. 13.

Loi sur les langues officielles, L.R.C. (1985), chap. 31 ( $4^{\mathrm{e}}$ supplément).

Loi sur les langues officielles, L.R.C. (1985), chap. O-3. Loi sur les langues officielles, L.R.T.N.-O. 1988, chap. $\mathrm{O}-1$.

Loi sur les langues officielles du Nouveau-Brunswick, L.R.N.-B. (1973), chap. O-1.

Loi sur les services en français, S.O. 1986, chap. 45.

The Official Language Act, S.M. 1890, chap. 14.

\section{Jurisprudence}

Bertrand c. Dussault, Cour de comté du Manitoba, 30 janvier 1909, (1977) 77 D.L.R. (3d) 458.

Blaikie $n^{\circ}$ 2, [1981] 1 R.C.S. 312.

La Reine c. Mercure, [1988] 1 R.C.S. 234.

Ottawa Separate Schools Trustees c. Mackell, [1917] A.C. 62.

Pellant c. Hébert, Cour suprême du Manitoba, mars 1892, (1981) 12 R.G.D. 242.

Procureur général du Manitoba c. Forest, [1979] 2 R.C.S. 1032.

Procureur général du Québec c. Collier, [1985] C.A. 559, confirmé par [1990] 1 R.C.S. 260.

Renvoi: Droits linguistiques au Manitoba, [1985] 1 R.C.S. 721.

Renvoi: Droits linguistiques au Manitoba, [1985] 2 R.C.S. 347.

Renvoi de 1992 sur les droits linguistiques au Manitoba, [1992] 1 R.C.S. 212.

Sinclair c. Procureur général du Québec, [1992] 1 R.C.S. 579.

Waite c. La Reine (1986), 25 D.L.R. (4th) 696, confirmé par (1987), 47 Man. R. (2d) 247 (C.A.).

\section{Doctrine \\ a) Réalité socio-historique \\ I) LIVRES}

Carrière, L. (1981): Les Français dans les Pays d'en Haut, Toronto, McGraw-Hill Ryerson.

Frémont, D. (1980): Les Français dans l'Ouest canadien, Saint-Boniface, Éditions du Blé.

Frémont, D. (1948): Les Métis de l'Ouest canadien, Ottawa, Société royale du Canada.

Giraud, M. (1984): Le Métis canadien, Saint-Boniface, Éditions du Blé.

JAENEN, C. (1976): Regards sur les Franco-Manitobains, Winnipeg, University of Winnipeg Press.

Lingard, C. (1946): Territorial Government in Canada - The Autonomy Question in the Old North-West Territories, Toronto, University of Toronto Press.

MacEwan, G. (1984): Les Franco-Canadiens dans l'Ouest, Saint-Boniface, Éditions des plaines.
Schneiderman, D. (1991): Langue et État: droit, politique et identité (Actes de la deuxième conférence sur les affaires constitutionnelles tenue par le Centre d'études constitutionnelles), Cowansville, Éditions Yvon Blais.

Sheppard, C-A. (1971): The Law of Languages in Canada, étude $\mathrm{n}^{\circ} 10$ de la Commission royale d'enquête sur le bilinguisme et le biculturalisme, Ottawa, Information Canada.

Tremblay, A. (1996) "Les droits linguistiques (articles 16 à 22)," dans Beaudoin, G.A. et Mendes, E.P. (dir.), Charte canadienne des droits et libertés, 3rd ed., Montréal, Éditions Wilson \& Lafleur.

(II) ARTICLES

Aunger, E. A. (1989): "Language and Law in the Province of Alberta," dans Paul Pupier et José Woehrling, Langue et droit: Actes du premier congrès de l'Institut international de droit linguistique comparé, Montréal, Wilson \& Lafleur, p. 203.

- (1998): "The Mystery of the French Language Ordinances: An Investigation into Official Bilingualism and the Canadian North-West 1870 to 1895 ," 13 R.C.D.S. 89-124.

Bale, G. (1985): "Law, Politics and the Manitoba School Question: Supreme Court and Privy Council," 63 Revue du Barreau canadien, 461518.

Beaudoin, G. (1993): "La protection constitutionnelle des minorités au Canada: un aperçu" dans Ernest Caparros (dir.), Mélanges Germain Brière, Collection Bleue, Montréal, Wilson \& Lafleur, 779-805.

Brä̈N, A. (1998): "Judicial Interpretation of Language Rights in Canada and the Beaulac Case," [En ligne], [http://www.pajlo.org/english/ pands/ouvrage/braen.pdf] (30 April 2001).

- (1998): "L’interprétation judiciaire des droits linguistiques au Canada et l'affaire Beaulac" 29 R.G.D. 379; [En ligne], 1998. [http://www. pajlo.org/francais/produits/ouvrage/braen-fr. pdf] (30 avril 2001).

Gibson, D. and K. Lercher (1986): "Reliance on Unconstitutional Laws: The Saving Doctrines and Other Protections," 15 Man. L.J. 305.

Jourdain, G. (1986): “L'article 23 sitôt revigoré, sitôt bafoué," 4 Télé-CLEF n 3, pp. 16-17.

_ (1987): "Le français à la législature du Manitoba: la Cour d'appel absout les gaffes de la province," 5 Télé-CLEF n ${ }^{\circ} 3$, pp. 14-16.

McConnell, W. H. (1989): "Bilingualism on the Prairies: The Constitutional Status of French in Saskatchewan," 53 Sask. L. Rev. 143-152.

Munro, K. J. (1991): "French Language and Educational Rights in Alberta: An Historical Perspective," in David Schneiderman (ed.), Langue et État: droit, politique et identité, Cowansville, Éditions Yvon Blais, p. 251. 
Morton, A. (1973): A History of the Canadian West to $1870-71,2^{\mathrm{e}}$ édition, Toronto, University of Toronto Press.

Painchaud, R. (1986): Un rêve français dans le peuplement de la Prairie, Saint-Boniface, Éditions des plaines.

Prud'homme, L.-A. (1904): L'élément français au Nord-Ouest: voyageurs canadiens français et Métis, 1763-1870, Montréal, Compagnie de la Revue canadienne.

\section{II) REVUes}

Aunger, E. A. (1993): "The Decline of a FrenchSpeaking Enclave: A Case Study of Social Contact and Language Shift in Alberta», 25 Canadian Ethnic Studies 65-83.

LAfontant, J. (2000) : «Les jeunes Franco-Manitobains et l'identité culturelle», Thèmes canadiens, numéro consacré à la dualité et à la diversité, 26-30.

Pelletier, B. (1994): «Les rapports de force entre les majorités et les minorités de langue officielle au Canada», 24 R.D.U.S. 256-292.

\section{b) Droits linguistiques \\ I) LIVRES}

Bastarache, M. et al. (1987): Language Rights in Canada, Cowansville, Éditions Yvon Blais.

Bastarache, M. et al. (1986) : Les droits linguistiques au Canada, Cowansville, Éditions Yvon Blais.

BLAY, J. (1987) : L'article 23: les péripéties législatives et juridiques $d u$ fait français au Manitoba, 18701986, Saint-Boniface, Éditions du Blé, 392 p.

Brun, H. et G. Tremblay (1997) : Droit constitution$n e l, 3^{e}$ édition, Cowansville, Éditions Yvon Blais.

Canada, Rapport de la Commission royale d'enquête sur le bilinguisme et le biculturalisme, livre I, Les langues officielles, Ottawa, Imprimeur de la Reine, 1967 (rapport Laurendeau-Dunton).

Foucher, P. (1985): Constitutional Language Rights of Official-Language Minorities in Canada, Ottawa, Canadian Law Information Council.

- (1985): Les droits scolaires constitutionnels des minorités de langue officielle du Canada, Ottawa, Conseil canadien de la documentation juridique.

Hogg, P. (1992): Constitutional Law of Canada, $3^{\text {e }}$ édition, Toronto, Carswell.

Keyes, J. M. (1992) : Executive Legislation: Delegated Law Making by the Executive Branch, Toronto, Butterworths.

LÉGER, Sylvie, dir. (1995): Les droits linguistiques au Canada: collusions ou collisions, Ottawa, Centre canadien des droits linguistiques.

Martel, A. (1991): Les droits scolaires des minorités de langue officielle au Canada: de l'instruction à la gestion, Ottawa, Commissariat aux langues officielles.
Pelletier, B. (1995): "Bilan des droits linguistiques au Canada," 55 Revue du Barreau 611-659.

- (1991): "Les réticences des provinces face à la reconnaissance de droits constitutionnels relatifs à l'usage des langues officielles," $51 R$. $d u B$. 247.

Riddell, A. (1988): “À la recherche du temps perdu: la Cour suprême et l'interprétation des droits linguistiques constitutionnels dans les années 80," 29 C. de D. 829.

Teffaine, R. (1992): "Éducation et francophonie dans l'Ouest canadien," 20 Éducation et francophonie [revue de l'Association canadienne d'éducation de langue française] (numéro spécial consacré aux actes du congrès intitulé Au-delà des différences, une francophonie à découvrir) 35-44.

- (1986): "Le champ d'application de l'article 23 de la Loi de 1870 sur le Manitoba," (1986), 4 Télé-CLEF n ${ }^{\circ} 1$, pp. 12-14.

\section{Legislative drafting}

(I) воокS

Agence de coopération culturelle et technique, Rédaction législative en contexte de pluralité juridique et de multilinguisme (Talence, Agence de coopération culturelle et technique, École internationale de Bordeaux, 1990).

Barreau du Québec, Rapport du Comité sur les techniques de législation (Montreal: Barreau du Québec, 1985).

BeAupré, R.M., Interprétation de la législation bilingue (Montreal: Wilson \& Lafleur, 1986).

- Interpreting Bilingual Legislation, 2nd ed. (Toronto: Carswell, 1986).

Centre d'études sur la coopération juridique internationale, Le français langue $d u$ droit (Paris: Presses universitaires de France, 2000).

Uniform Law Conference of Canada, Report of the Committee Appointed to Prepare Bilingual Legislative Drafting Conventions for the Uniform Law Conference of Canada (Internet: http:// www.law.ualberta.ca/alri/ulc/acts/edraft.htm 1996, last visited April 30, 2001).

Côté, P.-A. (1999): Interprétation des lois, 3rd édition, Montréal, Thémis.

- (2000): The Interpretation of Legislation in Canada, 3rd édition, Cowansville, Yvon Blais.

Didier, E. (1990): Langues et langages du droit: étude comparative des modes d'expression de la common law et $d u$ droit civil en français et en anglais, Montréal, Wilson \& Lafleur, 477 p.

Fernbach, N. (1990): La lisibilité dans la rédaction juridique au Québec, Ottawa, Centre de promotion de la lisibilité, Centre canadien de formation juridique, $128 \mathrm{p}$.

GAGné, L. (1997): Le processus législatif et réglementaire au Québec, Cowansville, Éditions Yvon Blais. 
Pupier, P. et J. Woehrling (1989): Langue et droit: Actes du premier congrès de l'Institut international de droit linguistique comparé, Montréal, Wilson \& Lafleur.

Schneiderman, D. (1991): Langue et État: droit, politique et identité (Actes de la deuxième conférence sur les affaires constitutionnelles tenue par le Centre d'études constitutionnelles), Cowansville, Éditions Yvon Blais.

Sheppard, C-A. (1971): The Law of Languages in Canada, étude $\mathrm{n}^{\circ} 10$ de la Commission royale d'enquête sur le bilinguisme et le biculturalisme, Ottawa, Information Canada.

Tremblay, A. (1996) «Les droits linguistiques (articles 16 à 22) ", dans Beaudoin, G.A. et Mendes, E.P. (dir.), Charte canadienne des droits et libertés, $3^{\mathrm{e}}$ édition, Montréal, Éditions Wilson \& Lafleur.

II) REVUES

Aunger, E. A. (1989): «Language and Law in the Province of Alberta ", dans Paul Pupier et José Woehrling, Langue et droit: Actes du premier congrès de l'Institut international de droit linguistique comparé, Montréal, Wilson \& Lafleur, p. 203.

— (1998): «The Mystery of the French Language Ordinances: An Investigation into Official Bilingualism and the Canadian North-West 1870 to 1895 », 13 R.C.D.S. 89-124.

Bale, G. (1985): «Law, Politics and the Manitoba School Question: Supreme Court and Privy Council », 63 Revue du Barreau canadien, 461518.

Beaudoin, G. (1993): «La protection constitutionnelle des minorités au Canada: un aperçu» dans Ernest Caparros (dir.), Mélanges Germain Brière, Collection Bleue, Montréal, Wilson \& Lafleur, 779-805.

BRAËN, A. (1998) : "Judicial Interpretation of Language Rights in Canada and the Beaulac Case», [En ligne], [http://www.pajlo.org/english/ pands/ouvrage/braen.pdf] (30 avril 2001).

_ (1998): "L'interprétation judiciaire des droits linguistiques au Canada et l'affaire Beaulac» 29 R.G.D. 379; [En ligne], 1998. [http://www. pajlo.org/francais/produits/ouvrage/braen-fr. pdf] (30 avril 2001).

Gibson, D. and K. Lercher (1986): «Reliance on Unconstitutional Laws: The Saving Doctrines and Other Protections », 15 Man. L.J. 305.

Jourdain, G. (1986) : "L'article 23 sitôt revigoré, sitôt bafoué», 4 Télé-CLEF n $\mathrm{n}^{\circ}$ 3, p. 16-17.

_ (1987): «Le français à la législature du Manitoba: la Cour d'appel absout les gaffes de la province », 5 Télé-CLEF n ${ }^{\circ} 3$, p. 14-16.

McConnell, W. H. (1989): "Bilingualism on the Prairies: The Constitutional Status of French in Saskatchewan », 53 Sask. L. Rev. 143-152.
GÉmAR, J.-C., dir. (1982): Langage du droit et traduction - Essais de jurilinguistique, Québec, Éditeur officiel du Québec, 320 p.

- (1995): Traduire ou l'art d'interpréter - langue, droit et société: éléments de jurilinguistique, Sainte-Foy, Presses de l'Université du Québec.

Justice Canada, Guide canadien de rédaction législative française (permanent edition) (Ottawa: Supply \& Services Canada, 1984).

Justice Canada, A Guide to the Making of Federal Acts and Regulations (Internet: www.canada.justice. gc.ca/en/jus/far/Index.htm 1995, last visited April 30, 2001).

Justice Canada, The Harmonization of Federal Legislation with the Civil Law of the Province of Quebec and Canadian Bijuralism (Internet: www. canada.justice.gc.ca/en/min/pub/hfl/table.htm 2001, last visited June 01, 2001).

Justice Canada, Manuel de la réglementation fédérale (Ottawa, Supply \& Services Canada, 1998).

Law Reform Commission of Canada, Drafting Laws in French (Ottawa: Supply \& Services Canada, 1981).

Law Reform Commission of Canada, La rédaction française des lois (Ottawa: Supply \& Services Canada, 1982).

Mowat, C. (1998): A Plain Language Handbook for Legal Writers, Scarborough, Carswell.

Pigeon, L.-P. (1986): Rédaction et interprétation des lois, $3^{e}$ édition, Québec, Publications du Québec, $156 \mathrm{p}$.

Snow, G. et J. VAnderlinden, dir. (1995): Français juridique et science du droit, Bruxelles, Bruylant.

Sparer, M. (1978): Propos sur la rédaction des lois, Québec, Conseil de la langue française, 235 p.

Sparer, M. et W. Schwab (1980): Rédaction des lois: Rendez-vous du droit et de la culture, Québec, Éditeur officiel du Québec, 349 p.

Tremblay, Journeault-Turgeon, R. et J. Lagacé (1984): Guide de rédaction législative, Montréal, Société québécoise d'information juridique, $129 \mathrm{p}$.

(II) ARTICLES

Covacs, A. (1979): "Bilinguisme officiel et double version des lois - un pis-aller: la traduction — une solution d'avenir: la co-rédaction," 24 Meta 103-108.

Duchesne, A. et R. Patry (1991): "La normalisation de la terminologie française de la common law," 24 Actualité terminologique, $\mathrm{n}^{\circ}$ 3, pp. 19-22.

GÉmAR, J.-C. (1994): "Le discours législatif et le langage du droit: rédaction, style et texte juridiques" 25 Revue générale de droit, 327-345

Issalys, P. (1998): "Histoire de la technique législative au Québec" dans Conférence des juristes de l'État, Actes de la XIII e conférence des juristes de l'État, Cowansville, Éditions Yvon Blais, 323-354. 
Munro, K. J. (1991): «French Language and Educational Rights in Alberta: An Historical Perspective», dans David Schneiderman (dir.), Langue et État: droit, politique et identité, Cowansville, Éditions Yvon Blais, p. 251.

Pelletier, B. (1995) : «Bilan des droits linguistiques au Canada », 55 Revue du Barreau 611-659.

- (1991): «Les réticences des provinces face à la reconnaissance de droits constitutionnels relatifs à l'usage des langues officielles", 51 R. du B. 247.

Riddell, A (1988): "À la recherche du temps perdu: la Cour suprême et l'interprétation des droits linguistiques constitutionnels dans les années 80 », 29 C. de D. 829.

Teffaine, R. (1992): «Éducation et francophonie dans l'Ouest canadien", 20 Éducation et francophonie [revue de l'Association canadienne d'éducation de langue française] (numéro spécial consacré aux actes du congrès intitulé Au-delà des différences, une francophonie à découvrir) 35-44.

Teffaine, R. (1986): «Le champ d'application de l'article 23 de la Loi de 1870 sur le Manitoba", (1986), 4 Télé-CLEF nº 1, p. 12-14.

\section{c) Rédaction législative \\ I) LivRes, protocoles et GUides}

Agence de coopération culturelle et technique, Rédaction législative en contexte de pluralité juridique et de multilinguisme, Talence, Agence de coopération culturelle et technique, École internationale de Bordeaux, 1990.

Barreau du Québec, Rapport du Comité sur les techniques de législation, Montréal, Barreau du Québec, 1985.

BeAupré, R. M. (1986): Interprétation de la législation bilingue, Montréal, Wilson \& Lafleur, $284 \mathrm{p}$.

- (1986): Interpreting Bilingual Legislation, $2^{\mathrm{e}}$ édition, Toronto, Carswell, $236 \mathrm{p}$.

Centre d'études sur la coopération juridique internationale, Le français langue $d u$ droit, Paris, Presses universitaires de France, 2000.

Commission de réforme du droit du Canada, Drafting Laws in French, Ottawa, ministère des Approvisionnements et Services, 1981, 296 p.

Commission de réforme du droit du Canada, La rédaction française des lois, Ottawa, ministère des Approvisionnements et Services, 1982, 270 p.

Conférence pour l'harmonisation des lois au Canada, Protocole de rédaction législative bilingue, [En ligne], 1996. [http://www.law.ualberta.ca/alri/ ulc/acts/fdraft.htm] (30 avril 2001).

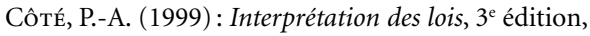
Montréal, Thémis.

- (2000): The Interpretation of Legislation in $\mathrm{Ca}$ nada, $3^{\mathrm{e}}$ édition, Cowansville, Yvon Blais.

Didier, E. (1990): Langues et langages du droit: étude comparative des modes d'expression de la
Keating, J. (1995): "La corédaction et l'expérience néo-brunswickoise," dans Gérard Snow et Jacques Vanderlinden (dir.), Français juridique et science $d u$ droit, Bruxelles, Bruylant, pp. 203 à 217.

Krongold, S. (1992): "Writing Laws: Making Them Easier to Understand," 24 Revue de droit d'Ottawa, 495-581.

Levert, L. (1995): "Bijuridisme et bilinguisme législatifs: un enjeu et un pari," dans Gérard Snow et Jacques Vanderlinden (dir.), Français juridique et science $d u$ droit, Bruxelles, Bruylant, pp. 255-266.

- (2000): Le défi de la rédaction législative bilingue au Canada, [En ligne] [www.ovea.net/rijef/ Templates/Lionel\%20Levert.htm) (30 avril 2001).

Moisan, M. (2000): La réalisation de textes législatifs bilingues en Ontario, [En ligne] [www.ovea. net/rijef/Templates/MOISAN.htm] (30 avril 2001).

Pardons, C. (1995): “Élaboration d'une terminologie française de common law — Réflexions sur les travaux du PAJLO au cours des dix dernières années," dans Gérard Snow et Jacques Vanderlinden (dir.), Français juridique et science $d u$ droit, Bruxelles, Bruylant, pp. 279294.

Pigeon, L.-P. (1982): "La rédaction bilingue des lois fédérales," 13 R.G.D. 177.

Sparer, M. (1980): "La stéréophonie législative, facteur de haute infidélité?," 21 C. de D. 599614.

(Special issue devoted to legal translation) 68 Circuit (Ordre des traducteurs, terminologues et interprètes agréés du Québec, Summer 2000)

(Special issue devoted to legal translation) (1987) 28:4 Cahiers de droit

(Special issue devoted to legal translation) (March 1979) 4:1 Meta

Pour une common law à notre image (Papers presented at the conference) (1997) 1:2 Revue de la common law en français

Harmonisation et dissonance: langues et droit au Canada et en Europe (Papers presented at the conference) (2000) 3 Revue de la common law en français, nos. 1 and 2 . 
common law et du droit civil en français et en anglais, Montréal, Wilson \& Lafleur, 477 p.

Fernbach, N. (1990): La lisibilité dans la rédaction juridique au Québec, Ottawa, Centre de promotion de la lisibilité, Centre canadien de formation juridique, $128 \mathrm{p}$.

GAGNÉ, L. (1997) : Le processus législatif et réglementaire au Québec, Cowansville, Éditions Yvon Blais.

GÉmAR, J.-C., dir. (1982) : Langage du droit et traduction - Essais de jurilinguistique, Québec, Éditeur officiel du Québec, 320 p.

- (1995): Traduire ou l'art d'interpréter - langue, droit et société: éléments de jurilinguistique, Sainte-Foy, Presses de l'Université du Québec.

Ministère de la Justice du Canada, Guide canadien de rédaction législative française, édition permanente, Ottawa, ministère des Travaux publics et des Services gouvernementaux, 1984.

Ministère de la Justice du Canada, Guide de rédaction des lois et règlements fédéraux, [En ligne], 1995. [www.canada.justice.gc.ca/fr/jus/far/Index. htm] (30 avril 2001).

Ministère de la Justice du Canada, L'harmonisation de la législation fédérale avec le droit civil de la province de Québec et le bijuridisme canadien, [En ligne], 2001. [www.canada.justice.gc.ca/fr/ min/pub/hfl/table.htm] ( $1^{\text {er }}$ juin 2001).

Ministère de la Justice du Canada, Manuel de la réglementation fédérale, Ottawa, ministère des Travaux publics et des Services gouvernementaux, 1998.

Mowat, C. (1998): A Plain Language Handbook for Legal Writers, Scarborough, Carswell.

Pigeon, L.-P. (1986): Rédaction et interprétation des lois, $3^{\mathrm{e}}$ édition, Québec, Publications du Québec, $156 \mathrm{p}$.

SNOw, G. et J. VANDERLINDEN, dir. (1995) : Français juridique et science du droit, Bruxelles, Bruylant.

Sparer, M. (1978): Propos sur la rédaction des lois, Québec, Conseil de la langue française, $235 \mathrm{p}$.

Sparer, M. et W. Schwab (1980) : Rédaction des lois: Rendez-vous du droit et de la culture, Québec, Éditeur officiel du Québec, 349 p.

Tremblay, Journeault-Turgeon, R. et J. Lagacé (1984): Guide de rédaction législative, Montréal, Société québécoise d'information juridique, $129 \mathrm{p}$.

II) REVUES

Covacs, A. (1979): «Bilinguisme officiel et double version des lois - un pis-aller: la traduction — une solution d'avenir : la co-rédaction », 24 Meta 103-108.

Duchesne, A. et R. Patry (1991) : «La normalisation de la terminologie française de la common law», 24 Actualité terminologique, n 3, p. 19-22.
GÉmar, J.-C. (1994) : «Le discours législatif et le langage du droit: rédaction, style et texte juridiques» 25 Revue générale de droit, 327-345

Issalys, P. (1998) : «Histoire de la technique législative au Québec» dans Conférence des juristes de l'État, Actes de la XIII conférence des juristes de l'État, Cowansville, Éditions Yvon Blais, 323-354.

Keating, J. (1995) : "La corédaction et l'expérience néo-brunswickoise », dans Gérard Snow et Jacques Vanderlinden (dir.), Français juridique et science $d u$ droit, Bruxelles, Bruylant, p. 203 à 217.

Krongold, S. (1992): "Writing Laws: Making Them Easier to Understand ", 24 Revue de droit d'Ottawa, 495-581.

Levert, L. (1995): «Bijuridisme et bilinguisme législatifs: un enjeu et un pari », dans Gérard Snow et Jacques Vanderlinden (dir.), Français juridique et science $d u$ droit, Bruxelles, Bruylant, p. 255-266.

- (2000): Le défi de la rédaction législative bilingue au Canada, [En ligne] [www.ovea.net/rijef/ Templates/Lionel \%20Levert.htm) (30 avril 2001).

Moisan, M. (2000): La réalisation de textes législatifs bilingues en Ontario, [En ligne] [www.ovea. net/rijef/Templates/MOISAN.htm] (30 avril 2001).

PArdons, C. (1995) : «Élaboration d'une terminologie française de common law - Réflexions sur les travaux du PAJLO au cours des dix dernières années ", dans Gérard Snow et Jacques Vanderlinden (dir.), Français juridique et science $d u$ droit, Bruxelles, Bruylant, p. 279-294.

Pigeon, L.-P. (1982) : «La rédaction bilingue des lois fédérales », 13 R.G.D. 177.

Sparer, M. (1980) : «La stéréophonie législative, facteur de haute infidélité?», 21 C. de D. 599-614.

Dossier thématique consacré à la traduction juridique, Circuit (magazine de l'Ordre des traducteurs et interprètes agréés du Québec), $\mathrm{n}^{\circ}$ 68, été 2000.

Numéro spécial consacré à la traduction juridique, revue Cahiers de droit, volume 28, $\mathrm{n}^{\circ} 4,1987$.

Numéro spécial consacré à la traduction juridique, revue Meta, volume 4, $\mathrm{n}^{\circ} 1$, mars 1979.

Numéro spécial consacré aux actes du colloque intitulé "Pour une common law à notre image", Revue de la common law en français, volume 1, $\mathrm{n}^{\circ} 2,1997$.

Numéros spéciaux consacrés aux actes du colloque intitulé «Harmonisation et dissonance: langues et droit au Canada et en Europe", Revue de la common law en français, volume $3, \mathrm{n}^{\mathrm{os}} 1$ et 2 , 2000 . 